\title{
Pedagogical considerations of the curricular incorporation of ICT
}

\section{Consideraciones pedagógicas de la incorporación curricular de las TIC}

\author{
OCAMPO-BOTELLO, Fabiola*, VERA-HERNÁNDEZ, Gumersindo and DE LUNA-CABALLERO, \\ Roberto
}

Instituto Politécnico Nacional, Escuela Superior de Cómputo

ID $1^{\text {st }}$ Author: Fabiola, Ocampo-Botello / ORC ID: 0000-0003-4407-5832

ID $1^{\text {st }}$ Coauthor: Roberto, De Luna-Caballero / ORC ID: 0000-0003-3524-4243

DOI: $10.35429 / J T E R .2019 .15 .5 .32 .39$

Received March 30, 2019; Accepted June 30, 2019

\begin{abstract}
The potential for the incorporation of Information and Communication Technologies (ICT) in education faces several challenges to consider, ranging from literacy and digital gaps, to varied simple or advanced levels of appropriation, from simple way of automating teaching activities for expository purposes or exchanging information to those teaching experiences that could hardly be developed without them. The process of incorporating ICT in the teaching task is a gradual, reflective and continuous process of permanent training that allows the teacher to develop educational experiences that modify the traditional way of teaching instruction, transformations that allow redesigning their educational practice with the purpose of creating meaningful learning in learners. With the intention of offering some of the initial considerations to be taken into account, this paper presents certain aspects to keep in mind in the inclusion of ICT in the design of activities for academic purposes.
\end{abstract}

\section{TIC, Digital gap, Technological appropriation}

\begin{abstract}
Resumen
El potencial de la incorporación de las Tecnologías de la Información y la Comunicación (TIC) en la educación enfrenta diversos retos a considerar, los cuales van desde la alfabetización y las brechas digitales, hasta los variados niveles simples o avanzados de apropiación, desde la simple forma de automatización de las actividades docentes con fines expositivos o el intercambio de información hasta aquellas experiencias docentes que difícilmente se podrían desarrollar sin estas. El proceso de incorporación de las TIC en el quehacer docente es un proceso gradual, reflexivo y continuo, de formación permanente que permite al profesor desarrollar experiencias educativas que modifican la forma tradicional de la impartición de instrucción, transformaciones que permitan rediseñar su práctica educativa con la finalidad de crear un aprendizaje significativo en los aprendices. Con la intención de ofrecer algunas de las consideraciones iniciales a tomar en cuenta, en este artículo se presentan ciertos aspectos a tener presentes en la inclusión de las TIC en el diseño de actividades con fines académicos.
\end{abstract}

Apropiación tecnológica, Brechas, TIC

Citation: OCAMPO-BOTELLO, Fabiola, VERA-HERNÁNDEZ, Gumersindo and DE LUNA-CABALLERO, Roberto. Pedagogical considerations of the curricular incorporation of ICT. Journal of Teaching and Educational Research. 2019 5-15: 32-39

\footnotetext{
* Correspondence to Author (email: focampob@ipn.mx)

$\uparrow$ Researcher contributing as first author.
} 


\section{Introduction}

Information and Communication Technologies (ICT) have been defined in various ways, in order to know their nature, some of these definitions are presented below.

Tinio (2003: 4) defines Information and Communication Technologies (ICT) as a diverse set of tools and technological resources used to communicate and create, disseminate, store and manage information, which include computers, internet, broadcasting technologies ( radio and television) and telephony.

Ávila Díaz (2013: 222) defines ICT as "the set of tools, supports and channels developed and supported by technologies (telecommunications, information technology, programs, computers and internet) that allow the acquisition, production, storage, treatment, communication, registration and presentation of information, in the form of voice, images and data, contained in signals of an acoustic, optical or electromagnetic nature in order to improve the quality of life of people".

The United Nations Development Program (UNDP, 2006: 56, cited in Orijuela, 2010: 114) defines ICT as "the set of technologies that allow the acquisition, production, storage, treatment, communication, registration and presentation of information contained in signals of an acoustic (sound), optical (images) or electromagnetic (alphanumeric data) nature, [...] and as instruments and processes used to retrieve, store, organize, manage, produce, present and exchange information by electronic means and automatic".

The above definitions reflect various aspects to be noted such as: the set of technological resources that incorporate tools with the purpose of establishing synchronous or asynchronous communication, storage and handling of information of different nature, as well as means for the transmission, representation and exchange of information.

Such characteristics and due to their ubiquitous nature that crosses spatial and temporal boundaries, have made them an option to diversify educational modalities and access to educational resources practically 24 hours a day, 7 days a week.
The interconnection of computers, synchronous, asynchronous communication, as well as the emergence of technological resources from the web favor the emergence of virtual communities of various types, people with similar interests, who communicate and exchange information, the creation of multimedia and hypermedia content For educational purposes it is currently carried out at a faster speed due to the large number of software tools available. The impact of the use of these technological resources is of great importance when they are properly incorporated into the school curriculum.

Cabero (2008) points out that ICTs enter the educational field with specific purposes aimed at strengthening the teaching and learning processes in issues associated with the creation of innovative contexts for academic training, expanding the information offer, creating environments flexible for learning, elimination of space-time barriers, increased educational modalities, enhancement of interactive environments, among others.

In this regard, Tinio (2003: 9) states that when ICTs are used properly, especially computers and internet technologies create new forms of teaching and learning, rather than simply allowing teachers and students to do what they traditionally do, but in a better way. These new forms of teaching and learning are supported by constructivist theories and change from being a teacher-centered pedagogy to a learner-centered environment. Although ICTs offer the opportunity to develop communication channels between the various actors in the educational process, there are certain aspects to consider in the inclusion of ICTs in education, which represents the objective of this article.

\section{Developing}

ICTs are here to stay, so at this moment it is necessary that the question of analyzing the impact they have to raise a new question that prevails in educational institutions regarding how to use them to increase educational quality (UNESCO, 2013) disappears. So there must be a change of perception that ceases to be focused on the technical aspects of equipment and the introduction of computer programs in one that considers the development of ICT skills from a pedagogical and reflective dimension of what they can contribute in the knowledge creation 
Although, at present there is a tendency to incorporate technologies in the realization of learning activities, without a thorough knowledge of the pedagogical contributions that support their presence, these activities become a way to automate what the teacher performs in their As a teacher, the reason for incorporation must be the result of continuous reflection, of a process through which experience is gradually gained and the visualization of ICTs not because of their own characteristics but because of what they can contribute to education.

ICTs bring great benefits to education, but at the same time challenges that must be analyzed in the process of incorporating them in this area, gaps that are relevant to identify to act as a result of a more fruitful use.

\section{Gaps in the incorporation of ICT in education}

ICTs currently face challenges related to the various gaps, one of them being the generation gap between educators and students, teachers and students who in their academic training received and receive instruction differently.

Similarly, the difference between these generations is related to the way they receive the information, the digital natives, the youngest, were born at a time when the Internet and the use of digital devices were part of the first devices with Those who had contact, but for that reason it cannot be assumed that they have all the appropriate knowledge to successfully enter ICT-mediated education.

The above reflects to some extent the importance of digital literacy, which according to Voogt et al. (2011, cited in UNESCO, 2013) "describes the basic skills related to ICTs that every person must manage to not be / be socially excluded. At the same time, by extension, it provides a base from which it is possible to develop new skills and competencies, through the options and innovations that allow access to ICTs. To the classic skills related to reading, writing and mathematics, students must add skills that allow them to feel comfortable with collaboration, communication, problem solving, critical thinking, creativity and productivity, in addition of digital literacy and responsible citizenship".
It has been so much the advancement of technology in recent years, that the previous expression highlights that digital literacy is something that citizens must learn so as not to be isolated, to maintain a presence in today's world, which could become a learning process. life. But, digital literacy, being optimistic, is a learning that can be acquired. There are other aspects that are also important in the incorporation of ICT in education, one of them being related to digital gaps.

The first digital divide also called the first-level digital divide or access gap became relevant in the late 1990s and studies on the use of technology highlighted the difference and risk created by technology between those who were digitally included and those who did not (Córica and Urías, 2017). Which is decreasing due to the cheaper that have had electronic devices causing currently more availability to acquire one of them with Internet access.

The first digital divide and digital literacy provide the instrumental basis for evolving in the educational use of technologies in education, but now there is a need to analyze the type of content that is accessed, the above is framed in the call second digital divide.

The second digital divide or secondorder digital divide is one that is presented not by access, but by the quality of the contents that are accessed causing cultural and intellectual differences in members of the same society (Córica y Urías, 2017; Sunkel, Trucco and Espejo, 2014).

The second digital divide has important impacts on the development of people's intellectual abilities and their consequent action in the circumstances of life, on the creation of conditions for the achievement of the proposed life goals, the use of information with a judicious point of view that allows them to address the veracity of the information circulating on the Internet and other aspects broken down in table number 1 . 


\begin{tabular}{|l|l|}
\hline \multicolumn{1}{|c|}{$\begin{array}{c}\text { Intellectually rich } \\
\text { student }\end{array}$} \\
\hline $\begin{array}{l}\text { He has knowledge of his } \\
\text { past, his traditions. }\end{array}$ & $\begin{array}{l}\text { He doesn't know his past, } \\
\text { his traditions. }\end{array}$ \\
\hline $\begin{array}{l}\text { It motivates the } \\
\text { interesting. }\end{array}$ & It is motivated by fun. \\
\hline $\begin{array}{l}\text { Focus value on } \\
\text { excellence. }\end{array}$ & $\begin{array}{l}\text { Focus the value on the } \\
\text { novelty. }\end{array}$ \\
\hline $\begin{array}{l}\text { Validate the information } \\
\text { you find on the Internet or } \\
\text { it reaches you from social } \\
\text { networks. }\end{array}$ & $\begin{array}{l}\text { It assumes as certain the } \\
\text { information it finds on the } \\
\text { Internet and forwards what } \\
\text { comes from social } \\
\text { networks } \\
\text { validating its veracity. }\end{array}$ \\
\hline $\begin{array}{l}\text { Build new levels of } \\
\text { information } \\
\text { transforms that } \\
\text { applicable learning in } \\
\text { your life project. }\end{array}$ & $\begin{array}{l}\text { Prioritize the amount of } \\
\text { novel and anecdotal data. }\end{array}$ \\
\hline $\begin{array}{l}\text { It sets goals and generates } \\
\text { conditions for things to } \\
\text { happen. }\end{array}$ & $\begin{array}{l}\text { Think that the time will } \\
\text { come to worry about the } \\
\text { future. }\end{array}$ \\
\hline $\begin{array}{l}\text { The challenge is in the } \\
\text { achievement. }\end{array}$ & $\begin{array}{l}\text { The challenge is in } \\
\text { fighting boredom. }\end{array}$ \\
\hline \multicolumn{2}{|c|}{ into } \\
\hline
\end{tabular}

Table 1 Comparison of intellectually rich and intellectually poor students

Source: Own elaboration considering what Corica y Urias has stated (2017)

The above table expresses important differences present in the effects of the second digital divide between intellectually rich and intellectually poor students, considerations that if not addressed could create a negative effect in several generations in the case of intellectually poor students, so it corresponds to educators to educate the apprentices about the importance of the quality of the content to which they have access, the development of a critical judgment of the information they receive online or through social networks, in a broad sense in an education digital that pursues positive ends, that has in mind the subject that you want to create in the digital age, an intellectually rich student.

The use of ICT according to educational needs can be visualized from various levels, which reflect the desired use of them, that is to say, the realization of academic tasks that without them could not be carried out, move from a low operational level level, in which communication with students and the exchange of digital resources is established as a way to automate the activities that are carried out daily at a level of real appropriation of technology.
Fernández Vallejo and McAnally (2015) point out that: "the appropriation of technology occurs when the individual is able to use any technological resource in any daily activity and in different contexts to which he associated his domain (Wertsch, 1998). In this regard, the author argues that one aspect that explains people's cognitive transformations is not precisely the acquisition of the tools themselves, but the set of practices that are developed around them, that is, the institutional framework in which they Acquire and use, in this sense, the impact of ICT is focused on the role they play as mediators in people's practices while using them, so that the result of the appropriation of technological tools, supposes the generation of a technological awareness in the individuals involved".

As expressed in previous paragraphs, the incorporation of ICT in educational practices requires a process of reflection, in which various actors participate. A task that represents a challenge in the creation of educational materials and practices that in its design and construction consider not only the nature of a digital resource, but the purpose of its consideration, what pedagogical contribution it has in student learning.

The progress in the appropriation of ICT implies a reflexive use that arises from the teacher, from the use of educational practices that promote meaningful learning, relating the new information with what they already have, involving permanent training (Valencia-Molina, et, al, 2016).

\section{ICT considerations in the classroom}

The World Summit on the Information Society (2003, cited in UNESCO, 2013) states that the accelerated progress of technologies provides great opportunities for development, considering their ability to reduce temporal and spatial spaces, facilitating the potential use of these technologies in benefit of millions of people worldwide.

This ubiquitous nature of ICTs can be used for charitable purposes such as education and to support the development of training capacities of the human being. 
From an educational point of view, the incorporation of ICT in the classroom modifies the roles of teachers and students, considering that students can acquire a greater level of responsibility and autonomy in their learning process causing the teacher to change their role of being the only source of information and knowledge (UNESCO, 2013).

The figure of the teacher as the only source of information and knowledge is exceeded by the increasingly diverse communication channels through which students receive information on occasions before the teacher, is now about creating learning communities where everyone They contribute their knowledge from various perspectives. Therefore, the incorporation of ICT in the curricular field entails varied levels of consideration.

Orijuela (2010) establishes certain considerations to keep in mind in the curricular integration of ICT, some of these are:

- The educational institutions must generate spaces for the congruence of the curricular design, making explicit the intentions and the development of this with the plans of action pertinent to the contexts and the consideration of the means of evaluation between the planned and the realized, with the intention of visualize new and better ways of learning and teaching (p. 118).

The integration must be established from its origin in the Institutional Educational Project (PEI), in which the will to combine technology, learning and teaching is visualized, in a productive experience that mobilizes students and teachers to change their paradigms and structures, so that there is an assimilation and accommodation in the ICT curriculum with the intention of truly becoming an educational innovation (p. 127).

In the generation of learning communities in which each of its members can learn and develop their abilities and skills that will be useful in present and future challenges (UNESCO, 2013).
The realization of a diagnosis in the educational institution where the process will be developed to identify the ICT integration needs of teachers, students, parents and managers, in addition to the levels of integration in which they meet the purpose to have relevant starting elements with the contexts and realities of the institution (p. 127).

The curricular integration of ICT frames the participation of various actors, contexts and purposes to be considered in an adequate institutional integration, since the creation of the PEI, emphasizing that the importance of this aspect lies in the pedagogical considerations that teachers make of them at a higher level, which represents continuous training and a reflective process of the design and implementation of activities that would not be possible without the consideration of technologies.

\section{An Integration Plan}

Technology, learning and teaching are an indispensable triad to consider in the process of planning the integration of ICTs, which should be gradual, taking advantage of the experience of various actors, which through various plans can reduce the generational difference existing among the participants, to cite an example, the Godfather Plan, proposed by Prensky (2001, cited in Orijuela, 2010) in which the student advises the teacher on the use of tools and thereby facilitates the learning process generating a true curriculum integration and interaction between digital natives (students) and digital immigrants (teachers).

The Godfather Plan offers multiple advantages over the experience of the teacher teaching the unit of learning or subject and the knowledge of the students in the management of technologies, so that a work binomial can be achieved, which considers the way in which that the students want the information and the development of learning activities to be presented, thereby shortening the need to train students in the management of technologies and the teacher's update on the advantages of them.

The authors of this work consider that this action plan can be an initial aspect for the development of innovative academic activities that in their realization cause significant learning in the academic training of the apprentice. 


\section{As an example of incorporating ICT}

To cite, gamification, based on the use of video game design elements in non-game contexts to make a product, service or application more fun, attractive and innovative, that arouses people's enthusiasm (Deterding , 2011, cited in OrtizColón, Jordán, and Agredal, 2018).

Gamification allows to maintain the interest and attention of the student in the development of academic activities.

For example, one of the activities carried out in class is the presentation of topics with a high theoretical content, in which it is important that students identify the characteristics of certain elements, a lower level cognitive level, according to the Bloom scale, associated only to remember characteristics of certain concepts, methods, paradigms. In this case, the design of an activity in which the differentiating characteristics of each of them are identified in advance, a kind of comparative chart that allows us to express their distinction. In this example, a gamification tool called Kahoot was used, which is a software resource that allows you to create reagent banks with four response options, being only one of them true, it is designed online and students access from their cell phones to answer and rate the number of students who answered each of them, generating in the end the podium of the first three places.

Prior to the presentation and discussion of the theoretical topic, the students had to study it and at the end of the exhibition they accessed the Kahoot with the key of the questionnaire, once all the participants were "connected", the evaluation began, appearing one a join the questions with the respective answer options and with a descending counter indicating the time to provide the respective answer.

Analyzing the above scenario, the advantage is that all students had an electronic device to perform the activity (BYOD, Bring Your Own Device), their Smartphone.

Figure number 1 shows the participation of a student in the development of this activity.

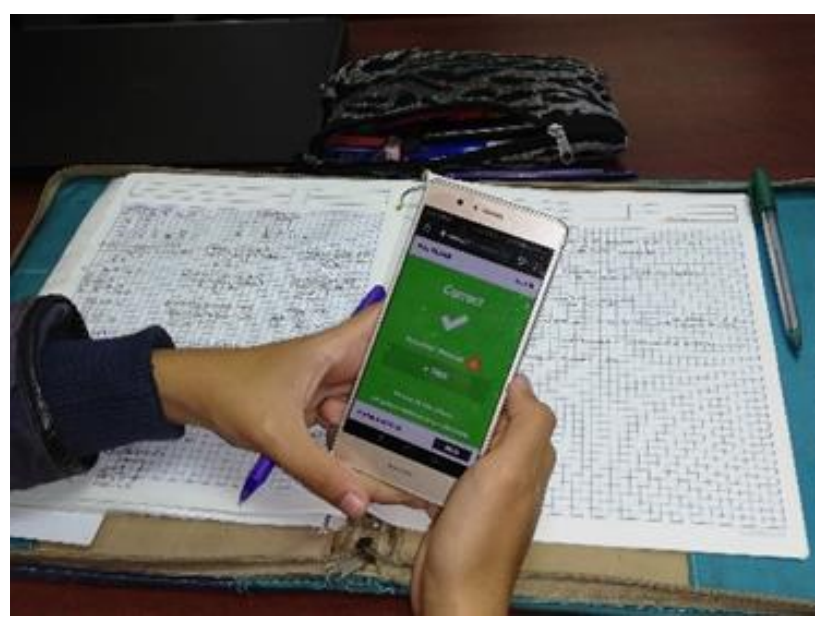

Figure 1 Alumna respondiendo el cuestionario en línea

One of the advantages of this type of software tools is that it allows an immediate evaluation of the answers that students provide to the questions that are made, generating a final evaluation of each of the participants. Situation that, without the support of technology, can hardly be so immediate due to the number of students present in the classroom. As mentioned earlier, technological resources of this type allow the development of diverse activities, in this case those associated to remember the meaning of basic concepts were exemplified, but they provide the basis for addressing activities of a higher cognitive level. The development of this activity allows to keep the attention of the student in the question that is asked due to the short period of time he has to answer, paying attention to the possible answers that would be reflected in the qualification he will get in that activity and obtain a qualification to carry out other tasks, together with an individualized evaluation since each student answers the questionnaire with their own device.

Other ICTs that can be incorporated in the development of academic activities are the educational software tools that incorporate lessons, solved and proposed examples, videos that consider various multimedia resources that stimulate the sensory aspects of the students, facilitating the subsequent memory of those exposed in the same. With the possibility of going back or stopping a video or playing it as many times as necessary until you consider that you have achieved your understanding, the videos are very adequate resources in the introduction of new subjects of study or to learn the handling of some equipment or product of software, something that can be complemented at other times with other resources such as digital books for further study. 
The simulators that allow to develop and test knowledge, generating conditions in short periods of time; the design of situations, manipulation and control of variables that can hardly be done without them, due to the time or economic costs that it is necessary to assume.

The software tools for the design of graphic organizers allow you to express through colors, shapes and figures what you want to convey, seeking in your creation the development of creativity, the identification of the most important concepts that are modeled, as well as the relationship and existing hierarchy between them. The ease of modifying them, of making approaches to express details of less relevance, the possibility of reproducing them as many times as necessary, as well as migrating them to other formats.

As stated, there is a wide variety of accessible, easy-to-use technological resources that allow the visualization of technological resources from another perspective and can be integrated into the teaching task, some of which, without being so sophisticated, allow to attract the attention of students, creating conditions for the development of activities for their academic training, the development of creativity. The incorporation of ICT in educational activities is a continuous process of reflection that goes from basic stages to others of a higher level, considering that the important thing in this type of ICT-mediated activities is based on the pedagogical reasons for its use

The integration of ICT in the teaching work is influenced by several aspects, which are related to the representation that teachers have of ICT, available ICT, the number of students, the intention of the teacher and the intention of the students, among others (Valencia-Molina, et, al, 2016).

\section{Conclusions}

The ubiquitous nature of ICT places them in a viable option for the development of educational software, the diversification of forms of communication, the creation of learning communities and the management of multimedia and transmedia resources to generate instructional experiences that satisfy the achievement of the objectives set and generate significant learning in the student.
In this sense, the role of teachers is essential, requires a process of preparation and continuous reflection to work towards overcoming the second-order digital divide (Córica y Urías, 2017; Sunkel, Trucco and Espejo, 2014), in working aspects of awareness and comprehensive training, of developing a critical judgment in students in the review of the materials and resources found on the Internet, in teaching students to work in the procurement of scenarios that allow them to achieve the objectives that have been raised, in general, in transforming what Corica and Urías (2017) call the profile of an intellectually poor student to an intellectually rich one. In the creation of learning communities, in which he is no longer the only source of knowledge and information, all participants can support the learning of others: student to teacher, teacher to student, student to student and all providing educational materials that allow enriching community learning.

It is not the most modern technology, nor the best equipped laboratory that will achieve a positive impact on the results of the consideration of ICT in education; The impact will be a reflection of the way in which teachers use them to create novel experiences, attractive to the student and that generate significant learning, of the pedagogical contributions that he discovers in them.

For example, the use of software for the design of graphic organizers can have a positive impact on students' significant learning, if the instruction considers creativity for their development, the identification, relationship and hierarchy of the aspects immersed in the subject of study, which will allow them to develop their ability to discriminate what is important from what is not.

The consideration of a group or virtual room that allows the creation of a learning community in which everyone learns from everyone, in which some ask at any time of the day and there is another that is "there" and answers, is not the teacher the only one who can handle the request; where due to its ability to store and transmit information material is shared that can be used to deepen the subject of study.

There are software tools that are easy to access and learn, even those that require a more specialized study for the development of an application for pedagogical purposes. 
The exposed in this article was carried out keeping in mind the need to know some of the aspects to consider in the inclusion of ICTs in education, as well as to emphasize the pedagogical nature they have, it is interesting to analyze the pedagogical contributions that ICTs have for increase the possibility of obtaining satisfactory results in the development of learning activities.

The appropriation of ICT in teaching is done gradually, little by little, generating pedagogical experiences that are proven in context and in reality (Unesco, 2013).

\section{References}

Ávila D., W. D. (2013). Hacia una reflexión histórica de las TIC. Revista Hallazgos. Vol. 10. No. 19. Pp. 213-233.

Cabero, A., J. (2008). Innovación en la formación y desarrollo profesional docente. En: Innovación educativa y uso de las TIC. Documento de la Universidad Internacional de Andalucía. Pp. 83-99.

Córica, J. L. y Urías M., M. (2017). La incorporación de TIC en educación: in mandato ético. En: Internet y educación: Amores y Desamores. Editores: Ávila Muñoz, Patricia y Rama Vitale, Claudio. Infotec Conacyt. Pp. 113130.

Fernández M. K.; Vallejo C. A. y McAnally S. L.. (2015). Apropiación tecnológica: una visión desde los modelos y las teorías que la explican. Perspectiva Educacional. Formación de Profesores. Vol. 54, núm. 2, junio. Pp. 109-125.

Orjuela F., D. L. (2010). Acercamiento a la integración curricular de las TIC. Praxis \& Saber. Vol. 1, núm. 2, julio-diciembre, 2010, pp. 111-136.

Ortiz-Colón, A. M.; Jordán, J. y Agredal, M. (2018). Gamificación en educación: una panorámica sobre el estado de la cuestión. Educ. Pesqui. Vol. 44.

Sunkel, G.; Trucco, D. y Espejo, A. (2014). La integración de las tecnologías digitales en las escuelas de América Latina y el Caribe. Una mirada multidimensional. Publicaciones Cepal.
Tinio, V. L. (2003). ICT in education. E-Primers for information economy, society and policy. Disponible en: http://www.eprimers.org/ict/page2.asp

Unesco. (2013). Enfoques estratégicos sobre las TIC en educación en América latina y el caribe. Documentos Unesco. Disponible en: http://www.unesco.org/new/fileadmin/MULTI MEDIA/FIELD/Santiago/images/ticsesp.pdf

Valencia-Molina, T.; Serna-Collazos, A.; Ochoa-Angrino, S.; Caicedo-Tamayo, A. M.; Montes-González, J. A. y Chávez-Vescance, J. D.. (2016). Competencias y estándares TIC desde la dimensión pedagógica: Una perspectiva desde los niveles de apropiación de las TIC en la práctica educativa docente. UNESCO-Pontifica Universidad Javeriana. Disponible en: http://www.unesco.org/new/fileadmin/MULTI MEDIA/FIELD/Santiago/pdf/Competenciasestandares-TIC.pdf

\section{Acknowledgments}

The authors of this article thank the Higher School of Computing of the National Polytechnic Institute for the support provided for the development of this work. 